\title{
CHARACTERISTICS OF THE ROMANIANS' RELIGIOSITY HIGHLIGHTED IN THEIR CHILDREN'S DRAWINGS
}

\author{
Daniela SOREA \\ "Transilvania" University of Brașov, Romania \\ sorea.daniela@unitbv.ro
}

\begin{abstract}
The religiosity of the contemporary Western World is marked by the process of secularization that strengthens atheism, but it evolves to a post-secular stage of recovering the values of Christianity in models of good social practices. Contemporary Western religiosity is also characterized by the revival of pre-Christian local beliefs and practices and the spread of new, imported forms of spirituality. Religiosity is a hard to tackle research topic, due to the reluctance of people to talk about their beliefs. Analyzing how children draw God is a way to overcome this difficulty. In the former socialist states of Europe, these characteristics intertwine with the effects of exiting from an atheistic programmatic political regime. Theoretical coding of drawings made on request by Romanian primary school pupils in 2004 and 2016 provides information on children's religiosity. They provide information on how Romanians see themselves on account of their religiosity compared to the trends of evolution of Western religiosity, as well as on the effects of introducing religion as a subject of study in Romanian schools.
\end{abstract}

Keywords: religiosity, drawings, children, secularization

\section{Introduction}

One of the first requests to the new regime in Romania at the end of 1989 was made by the Holy Synod of the Romanian Orthodox Church (Romanian: Biserica Ortodoxă Română, BOR) and concerned the reintroduction of Religion classes in schools. This was considered a priority by the aforementioned establishment.

The current paper outlines how Romanian students who graduate elementary school represent God. It also highlights as hypotheses the changes underwent by this representation between 2002 and 2016 - a time interval when the data was collected in two sequences as part of the seminar protocols for the discipline Sociology of Religion conducted at Transilvania University in Brașov with the third year students in Sociology. The data collected consist of drawings made by children and accompanied by their explanations that were thereupon coded.

The current paper does not analyze the drawings from a psychological perspective. It focuses on what children willingly and explicitly express in their drawings.

\section{Methodological specifications}

77drawings were collected from school children in urban and rural areas from the counties of Brasov and Covasna. 33 boys and 34 girls declared their genre, whereas 10 of the drawings have an unknown author. Most of the subjects were of Eastern Orthodox religion (only five were Catholics, Protestants, Neo-Protestants and Jehova's witnesses). 65 drawings were 
made in 2004 and twelve in 2016.

The drawings were made upon request. The children were asked to draw God and then to explain their drawings and answer the question "What is it that you know about God?". The drawings were made either in school (at teachers' requests but not during Religion classes) or at home.

I believe that the method of collecting and analyzing drawings is adequate for the topic of my study for two reasons. First, data collection via drawings is fit for the age of the subjects. Children draw a lot and with pleasure. Additionally, children find it difficult, it takes effort on their behalf to answer questions of abstract nature and their answers are not that eloquent. Second, religion and religiosity are research themes for which the sociological investigation does not yield trustworthy results. To approach children, researchers need to avoid direct, neutral questions that can trigger rejection [1]. The drawing technique is a comfortable manner of overcoming these difficulties. Moreover, concerning the aforementioned reasons, the graphic elicitation potential of drawings is welcome.

Children's drawings, explanations and answers are considered social documents elicited upon request and they were organized and analyzed with the support of NVivo 10. I coded data from a theoretical standpoint, classified them in emerging categories and these are presented below.

\section{Historical landmarks}

The religiosity of the contemporary West is characterized by secularization, a process that is typically Western [2], [3], that has two main dimensions, the loss of social power by religion and the diminishing of individual piety [4], and that favors atheism [5]. Moreover, contemporary Western religiosity is characterized by the revitalization of beliefs and pre-Christian local practices [6], as well as by the spread of new imported forms of spirituality [7]. That questions the irreversible by necessity nature of secularization. Lambert [8] and Hamberg [7] indicate a slowdown and even a turnaround of the process.

Rorty, Vattimo [9] and Girard [10] highlight the post-secular tendency to retrieve Christian love from the values that configure current public policies in Western democracies: support, charity, community development, friendly help, and social cohesion. In the former socialist states in Europe these features are interwoven with the effects of having been under atheist regimes.

The request of the Holy Synod of the BOR made in January 1990 results first in the acceptance by the Ministry of Education to introduce one facultative class of "moralreligious education" to be conducted every two weeks in primary and secondary schools. In the 90s the status of these classes gradually consolidates. In the school year 1991-1992 these classes are taught once every week and as of 1993 the discipline is called "Religion". The Education Law of 1995 (84/31 July 1995) declares the Religion class compulsory for primary schools, optional for secondary schools and facultative for high schools and vocational schools. The choice of religious affiliation is made with parents' or legal guardians' written consent. Upon the latter's written request, children may not attend Religion [11].

The Emergency Ordinance of 1997 $(36 / 1997)$ removes the status distinction concerning Religion classes in the three educational stages and these become part of the core curriculum.

The 1999 version of the law maintains the option of opting out in writing not to participate in Religion classes. Human rights activists perceive the presence of this paragraph as insufficient in terms of guaranteeing the freedom of conscience. They claim that the alternative of expressing the consent to participate in such classes in writing would be more adequate [11]. The challenges raised during the $90 \mathrm{~s}$ are followed by others later on. 
The Education Law no 1 of 2011 also maintains the possibility to opt out in writing not to participate in Religion classes. The article referring to that (18.2) is challenged and declared unconstitutional in 2014. Ever since, a written plea to take part in those Religion classes must be handed in to the school.

Thus, at the beginning of the 90s, civil society and the state via its Ministry of Education enthusiastically support the introduction of Religion classes in schools. Nonetheless, the situation has dramatically changed lately. The trend is one of accelerated secularization and corresponds to the evolution model of religiosity in the countries of the former communist bloc established by Norris and Ingelhart in 2012 [12]. The two researchers indicate that after two decades of a compensatory growth of religiosity after the fall of communism and as a result of an increase in the social and financial security, post communist societies have settled for the secularization trend.

But this trend is not reflected by children's religiosity. In parallel with the attitudes expressed by the representatives of civil society and state, the BOR as representative of the main denomination in Romania has been working towards consolidating the status of Religion in schools. Right after 1989, Religion classes are taught by students of Theology, priests and teachers specialized in other subject matters. Intensive pedagogical and methodological training is organized for these [11] before theological institutes establish pedagogical education and thus a double specialization for their graduates (starting with the 19911992 academic year). Religion textbooks have also changed their catechetical approach inspired by inter-war models and adopted in the 90s [11] to methods that are more appropriate for the profile of nowadays' students.

\section{Research results}

I considered that the effects of teaching Religion to children can be identified in the latter's representation of God.

I used open coding to interpret the drawings and their explanations, considering these cases in NVivo. I subsumed the emerging categories and subcategories to some axial categories. The numbers accompanying the names of categories and subcategories indicate the number of drawings/ the number of codes for these: Canonical marks (50/96)/ Canonical contexts (43/70)/ God is outworldly (40/74)/ God is friendly (35/42)/ God's humanity (23/30)/ Noncanonical representations (6/6) Worshippers at the church (3/5).
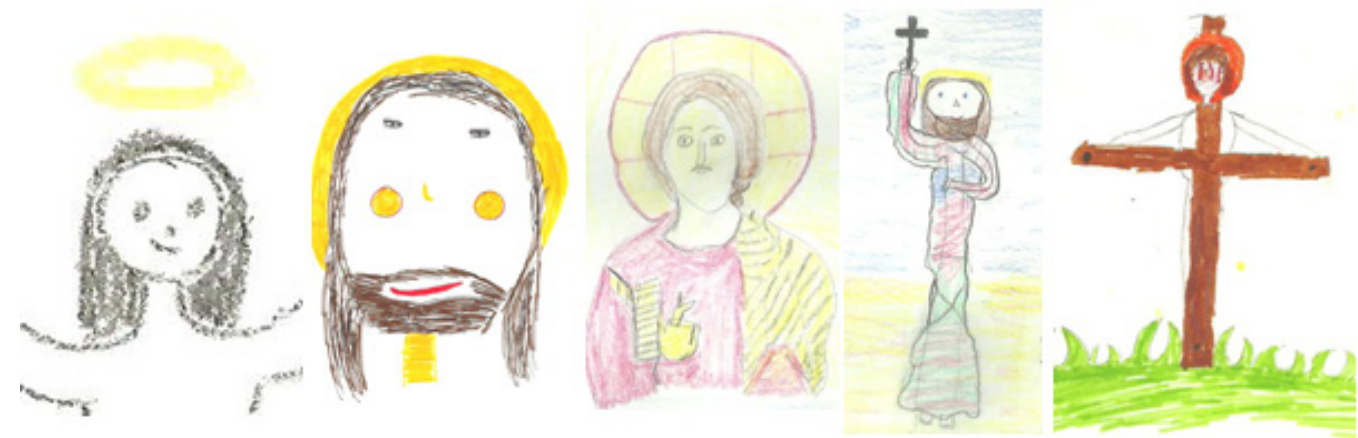

Figure 1: Canonical marks and canonical contexts

I subsumed the codes related to God's attributes drawn in accordance with classical icon representations to the axial category Canonical marks. This category includes representations characteristic of the icons picturing Jesus Christ (24/48), various graphical representations of the aura $(28 / 28)$ and of the canonical outfit to be found in the icons portraying saints $(17 / 17)$.

The axial category Canonical contexts includes representations of some Biblical 
scenes, postures or symbols. The most frequent are those of the cross $(19 / 20)$ or of the Crucifixion (13/23).

The axial category God is outworldly includes representations of God's otherness, of the "ganz Andere" feeling associated by R. Otto to Him [13].
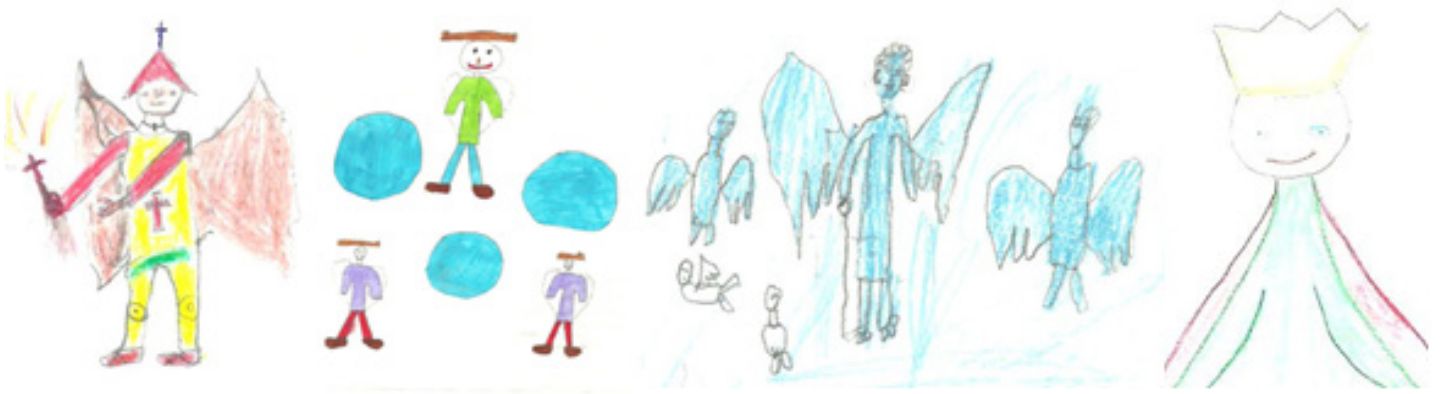

Figure 2: God is outworldly

Unlike the aura that is coded in the category Canonical marks because its representation is the effect of icons' outward influence on children's conscience, the codes in the category God is from another world are the expression of children's personal individual acknowledgment of God's status. Therefore, I also coded here the presence of angels around Him (12/14), as well as the references made to the sky (12/13) and Heaven (9/14) as God's abodes. Besides God's representation among angels, in the sky or in Heaven, the category God is outworldly subsumes the use of golden yellow as God's color (11/11), marks of His royalty $(7 / 9)$, rays that emerge from Him $(5 / 5)$, as well as some representations like God as an angel, His huge body-build, the partially unseen silhouette or his presence among the stars.

The category God is friendly mainly subsumes representations of God's smile (27/27) and of His arms widely opened for hugging (4/4). In the next category, God's humanity, I classified His human posture (14/14), the clothing (9/9) and His human silhouette (7/7). The category Noncanonical representations (6/6) includes some representations that canonically speaking are not of Christian origin but yet they can be found in other religions, namely God as a woman, God among the flowers of the world, God as a blue star, etc. In the category Worshippers at the church, I classified the drawings in which God's presence is implied through a drawn church with believers heading towards it.

The drawings are made by four graders. According to Jean Piaget's stages of learning [14] these children are in the concrete-operational stage. Most of the drawings come from Orthodox children (72 of 77) and along with the explanations they delineate God's representation in accordance with the canons of the Orthodox denomination. The codes classified in the categories Canonical marks and Canonical contexts are the most numerous (all in all they appear in 71 of the 77 drawings). The children who made the drawings are familiar with icons (most of the codes are related to details from icons) and with the Orthodox catechesis. At the same time, the presence of codes in the category God is outworldly shows children's capacity to grasp the canonical information and to manage the concept of God at individual personal level. The codes of the categories God is friendly and God's humanity indicates a positive informal attitude towards Him. Neither children's gender, nor their residential area impacts their representations. In the 2004 drawings there are high differences in the quality of the graphical representation and conceptual operation between the children in the city (their drawings are more elaborate and clearer) and those in the rural area. Such differences are a tell tale sign of the variations in the quality of the educational 
process in Romania but they do not bear any significant consequences on research results.

The codes belonging to children of other religions are frequently encountered in the drawings of the Orthodox children, as well. Their classification by the categories of Canonical marks and God is outworldly which are both rich in codes does not impact the comparative approach of the two collections of drawings.

The decreasing ordering of categories by the frequency with which their codes appear is different in the two collections of drawings. The ordering in the 2004 collection is: Canonical marks/Canonical representations/ God is outworldly / God is friendly/ God's humanity/ Non-canonical representations, whereas the ordering of categories in the 2016 collection is: Canonical marks/ God is outworldly / God is friendly/ Canonical representations/ The Church/ God's humanity/ Non-canonical representations. The differences in size between the two collections turn the interpretations concerning the evolution of God's representations between the two time periods into mere hypotheses.

\section{Discussions and conclusions}

The study Childish Representations of God. An analysis of the drawings made by Romanian Children between 2004-2016 [15] analyzes the representations of six and seven year old children drawings to the same two collections. The findings of that study show good catechetic understanding. That is also valid for the current investigation, which additionally reveals representations of God's otherness and His smiling face. Moreover, God's presence as a guardian and father is also well coded in children's drawings and it is obvious that this is tributary to the education they get in their families. However, the comparison between the two collections shows in 2016, in the case of the six and seven year olds, increasing dogmatic freedom in representing God's otherness, as well as in their non canonical representations to the detriment of canonical representations. This trend actually corresponds to a time when the task of initiating children into religion is assumed by parents and no longer by grandparents (those who talk to children about God in 2016 are the former and not the latter).

In this context, the effect of conducting Religion classes, which becomes visible when children graduate from elementary school, resides in consolidated canonical representations. That is obviously a predictable impact. It is accompanied by the loss in the importance assigned to God's guarding dimension (to be found only in few of the codes in the category God is friendly) and in children's diminished freedom to represent God in accordance with their own capacity to understand. Their option to draw God by resorting to a ready available catechetic solution actually suggests that they do not assume His representation on a personal level. Compared to their younger colleagues, four graders rather draw God in accordance with what they were told about Him and less based on their own perception.

Thus, Religion classes familiarize children with canonical Christianity. On the other hand, both in the case of the six and seven year olds', and the four graders' (even though concerning the latter the statement is but a hypothesis) drawings of 2016 there is an increased freedom in representing God (and inherently a greater willingness to assume the representation at a personal level) compared to the 2004 collection. In my opinion, this evolution is the result of overlapping the modernization of textbooks and didactic approaches to the Religion classes with the secularization trend to be identified in the relation of civil society and state with the church. If for every generation Religion classes impose limitations in terms of the options made available for representing God, the time period elapsed between the two collections of drawings shows children's increased 
freedom in personalizing their relation with God.

Norris şi Ingelhart [12] associate the trend leading to secularization to a return to atheism. Nonetheless, children's drawings do not indicate any such situation. The codes in the category God is outworldly rather suggest a spiritual orientation that goes beyond Christianity, namely an alignment to a Western trend in this respect that is discussed by Hamberg [7]. The finding can also be viewed from the perspective of a new form of tolerance to pre-Christian religiosity which is actually a feature of the Romanian Orthodox denomination [16] and that is retrievable in a European trend. Maybe the orientation to atheism becomes manifest in their teens when children begin to rebel.

Either way, the relation between the purpose of introducing religious education in schools and the effects of this decision on children's religiosity is worth a rigorous analysis by the Church (churches) and schools. This analysis should have in its background a reluctant approach to secularization. The latter, at least in the form of individuals' reduced piety [4] is not captured by children's drawings. It is too early for such a representation, as it is too early in Romania, a country with a majority Orthodox denomination, for a post-secular retrieval of Christian love as the foundation for public policies.

\section{References}

[1] Wilson, B., Religia din perspectivă sociologică, Bucureşti, Ed. Trei, 2000.

[2] Dueck et al., Western Cultural Psychology of Religion: Alternatives to Ideology. Pastoral Psychology, No.66, pp. 397-425, 2017.

[3] Nikiforova, B., Cultural and religious dimensions of the sacred and profane ambivalence: the Vilnius case, Studies in East European Thought, pp.1-12, 2017.

[4] Dobbleare, K., The Meaning and Scope of Secularization, in P. B. Clarke (ed.), The Oxford Handbook of the Sociology of Religion, Oxford, Oxford University Press, pp. 599-615, 2011.

[5] Bainbridge, W. S. Atheism, in P. B. Clarke (Ed.), The Oxford Handbook of the Sociology of Religion, Oxford, Oxford University Press, pp. 319-335, 2011.

[6] Rountree, K., Native Faith and indigenous religion: a case study of Malta within the European context, Social Anthropology, Vol. 22, No.1, pp. 81-100, 2014.

[7] Hamberg, E. M., Unchurched Spirituality, in P. B. Clarke (Ed.), The Oxford Handbook of the Sociology of Religion, Oxford, Oxford University Press, pp. 742-757, 2011.

[8] Lambert, Y., New Christianity, Indifference and Diffused Spirituality, in H. Mcleod and W. Ustorf (Eds.), The Decline of Christendom in Western Europe 1750-2000, Cambridge, Cambridge University Press, pp. 63-78, 2003.

[9] Rorty, R., Vattimo, G., Viitorul religiei. Solidaritate, caritate, ironie, Pitești, Paralela 45, 2008.

[10] Girard, R., Vattimo, G., Adevăr sau credinţă slabă? Convorbiri despre creştinism şi relativism, București, Curtea Veche, 2009.

[11] Conovici, I., Ortodoxia în România postcomunistă, Cluj-Napoca, Eikon, 2010.

[12] Norris, P., Inglehart, R., Sacred and secular: Religion and politics worldwide, Cambridge, Cambridge University Press, 2012.

[13] Otto, R., Sacrul, Cluj-Napoca, Dacia, 1992.

[14] Piaget, J., Psihologia inteligenţei, București, Editura Didactică și Pedagogică, 1965.

[15] Sorea, D. Childish Representations of God. An analysis of the drawings made by Romanian Children between 2004-2016,unpublished.

[16] Eliade, M., Istoria credințelor și ideilor religioase, Iași, Polirom, 2011. 